\title{
CONCENTRATIONS OF NICKEL, LEAD AND CADMIUM IN RICE PLANT AS AFFECTED BY FARMYARD MANURE Hammad, S. A. ${ }^{*}$; E.S. Naeem ${ }^{\star *}$ and Howida B. El-habet ${ }^{* *}$ * Soil Sci. Dept. of Agric., Mansoura Univ., Egypt. \\ ${ }^{* *}$ Rice Research and training Center Sakha, Kafr EL-Sheikh
}

\begin{abstract}
The concentrations of cadmium $\left(\mathrm{Cd}^{2+}\right)$, nickel $\left(\mathrm{Ni}^{2+}\right)$ and Lead $\left(\mathrm{Pb}^{2+}\right)$ in different organs of rice plant were investigated by field experiments. Data showed that the highest yield of rice grain was recorded by the application of 21.42 tons farmyard manure (FYM) plus $357 \mathrm{~kg}$ urea.ha $^{-1}$ as compared with the other treatments. Roots accumulated more $\mathrm{Pb}^{2+}, \mathrm{Ni}^{2+}$ and $\mathrm{Cd}^{2+}$ than straw and grains at harvest stage of rice growth. $\mathrm{Pb}^{2+}, \mathrm{Ni}^{2+}$ and $\mathrm{Cd}^{2+}$ concentration in rice plant organs (root, straw and grain) increased with increasing levels of FYM either alone or in combined with urea compared with the control. $\mathrm{Pb}^{2+}$ concentrations in straw do not exceed the critical limits of pollution with FYM added to the soil either separated or combined with urea. However, rice grains were slightly polluted at 21.42 tons FYM plus $238 \mathrm{~kg}_{\text {urea.ha }}{ }^{-1}$ and 21.42 tons FYM plus $357 \mathrm{~kg}$ urea. $\mathrm{ha}^{-1}$. $\mathrm{Ni}^{2+}$ concentration in rice grain and straw do not exceed the critical limits with all treatments. $\mathrm{Cd}^{2+}$ concentration in rice straw do not exceed the critical limits of $\mathrm{Cd}^{2+}$ at all addition levels of FYM added to the soil whether levels separated or integrated with urea, however $\mathrm{Cd}^{2+}$ concentration in rice grain was polluted at 21.42 tons plus $238 \mathrm{~kg}$ urea.ha ${ }^{-1}, 14.28$ tons FYM plus $357 \mathrm{~kg}$ urea.ha ${ }^{-1}$ and 21.42 tons FYM urea.ha ${ }^{-1}$. Integration of 14.28 tons FYM plus $238 \mathrm{~kg}$ urea.ha ${ }^{-1}$ do not exceed the critical limits of the concentration of $\mathrm{Pb}^{2+}, \mathrm{Ni}^{2+}$ and $\mathrm{Cd}^{2+}$ in different organs of rice plant.
\end{abstract}

\section{INTRODUCTION}

All trace elements are toxic and in small quantities may are essential for plant growth ( $\mathrm{Fe}, \mathrm{Mn}, \mathrm{Mo}$ and $\mathrm{Zn}$ ). However excessive quantities will cause undesirable accumulation in plant tissue and growth reduction. Lead, Nickel and Cadmium are metals which have been found to have deleterious effects on both plant metabolism and human (Allinson and Dzilo 1981). Lead cause changes in the permeability of cell membrane and reactions of sulphydral groups (-SH) (Kabata Pendias and Pendias 1992). There is no evidence of an essential role of $\mathrm{Ni}^{2+}$ in plant metabolism, although the reported beneficial effects of $\mathrm{Ni}^{2+}$ on plant growth have stimulated speculation that this metal may have some function (Mengel and Kirkby 1987). Cadmium is phytotoxic, as it can interfere with photosynthetic and respiratory activities, mineral nutrition, enzymatic activities, membrane functions and hormone balance (Chen, 2000). The critical concentrations of $\mathrm{Pb}^{2+}, \mathrm{Ni}^{2+}$ and $\mathrm{Cd}^{2+}$ in plant ranged between 10 to $20 \mathrm{mg} \mathrm{Pb} \cdot \mathrm{kg}^{-1}, 10$ to $100 \mathrm{mg} \mathrm{Ni}^{-1} \mathrm{~kg}^{-1}$ and 5 to $30 \mathrm{mg} \mathrm{Cd}{ }^{2+} \cdot \mathrm{kg}^{-1}$ dry matter respectively (Mengel and Kirkby 1987 and Alloway 1995). Based on the levels of $\mathrm{Pb}$ and $\mathrm{Cd}^{2+}$ in polished rice grains, Kanso et al,(2000) divided lowland rice areas into three categories : $\mathrm{Pb}^{2+}<$ 0.5 and $\mathrm{Cd}^{2+}<0.12 \mathrm{ppm}$ unpolluted grains, $\mathrm{Pb}^{2+} 0.5-1$ and $\mathrm{Cd}^{2+} 0.12-0.24$ ppm slightly polluted grains and $\mathrm{Pb}^{2+}>1 \mathrm{ppm}$ and $\mathrm{Cd}^{+2}>0.24 \mathrm{ppm}$ polluted 
grains. The food chain is considered the main tract for transfer of trace elements to humans. The excess of $\mathrm{Pb}^{2+}$ may cause several health effects; nervous system disorder, hematologic effects, kidney disease, hypertension. $\mathrm{The} \mathrm{Ni}^{2+}$ excess caused mainly gastric, liver and kidney defects, neurological effects, emphysema and lung cancer. $\mathrm{Cd}^{2+}$ is one of the most toxic metals to humans, which cause cardiomyopathy, pneumonitis and osteomalacia (Kabata pendias and mukherjee 2007).

The objective of this study was to examine the effect of FYM under irrigation with wastewater on:

1) Rice grain yield.

2) Concentration of $\mathrm{Pb}^{2+}, \mathrm{Ni}^{2+}$ and $\mathrm{Cd}^{2+}$ in different rice plant organs at harvest

(Roots, Straw, Whole grain, husk and white grain).

\section{MATERIALS AND METHODS}

Two field experiments were conducted at Rice Research \& Training Center (RRTC) at the farm of Kafr El-Sheikh using rice plant (Oryza Sativa), Giza178 variety during 2007 and 2008 seasons. The present work at the first experiment aimed to study the effect of waste water and Farm yard manure on 1) Rice grain yield and 2) Concentration of $\mathrm{Pb}^{2+}, \mathrm{Ni}^{2+}$ and $\mathrm{Cd}^{2+}$ in different rice plant organs at harvest (Roots, Straw, Whole grain, husk and white grain). Soil sample was taken and subjected to chemical analysis followed the standard procedures by cottenie et al., (1979) and page et al., (1982) and the results were presented in Table 1.

Farm yard manure (FYM) incorporated with soil before transplanting and urea was added in two splits, $2 / 3$ before flooding and $1 / 3$ one month after transplanting. Plots were fertilized with super phosphate $(15 \%)$ at the rate of $100 \mathrm{~kg} \mathrm{fed}^{-1}$ before flooding. The experimental design system of layout was randomized complete block with four replications. The treatments at the first experiment were as follows:

1) Control denoted as $\mathrm{N}_{0} \mathrm{~F}_{0}$.

2) 7.14 tons farm yard manure (FYM) .ha ${ }^{-1}$ denoted as $\mathrm{N}_{0} \mathrm{~F}_{1}$.

3) 14.28 tons (FYM) $\cdot$ ha $^{-1}$ denoted as $\mathrm{N}_{0} \mathrm{~F}_{2}$.

4) 21.42 tons (FYM) $\cdot$ ha $^{-1}$ denoted as $\mathrm{N}_{0} \mathrm{~F}_{3}$.

5) $109.48 \mathrm{~kg} \mathrm{~N}$. ha ${ }^{-1}\left(238 \mathrm{Kg}\right.$ urea.fed $\left.{ }^{-1}\right)$ denoted as $\mathrm{N}_{1} \mathrm{~F}_{0}$.

6) $109.48 \mathrm{~kg} \mathrm{~N}$. ha ${ }^{-1}+7.14$ tons (FYM) denoted as $\mathrm{N}_{1} \mathrm{~F} 1$.

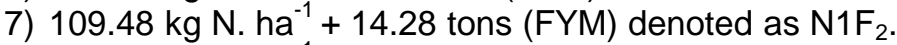

8) $109.48 \mathrm{~kg} \mathrm{~N}$. ha ${ }^{-1}+21.42$ tons (FYM) denoted as N1F3.

9) $164.22 \mathrm{~kg} \mathrm{~N}$. ha ${ }^{-1}\left(357 \mathrm{Kg}_{\text {urea.fed }}{ }^{-1}\right)$ denoted as $\mathrm{N}_{2} \mathrm{~F}_{0}$.

10) $164.22 \mathrm{~kg} \mathrm{~N}$. ha ${ }^{-1}+7.14$ tons (FYM) denoted as $\mathrm{N}_{2} \mathrm{~F}_{1}$.

11) $164.22 \mathrm{~kg} \mathrm{~N}$. ha ${ }^{-1}+14.28$ tons (FYM) denoted as $\mathrm{N}_{2} \mathrm{~F}_{2}$.

12) $164.22 \mathrm{~kg} \mathrm{~N}$. ha ${ }^{-1}+21.42$ tons (FYM) denoted as $\mathrm{N}_{2} \mathrm{~F}_{3}$.

The nursery was fertilized with recommended dose of N, P and $\mathrm{Zn}$. It's irrigated with drainage water (wastewater + agricultural drainage water). Plants in each plot were harvested for grain yield. Plants were left for drying about three days, and then threshed. The weight of grains was recorded and moisture content was measured then grains weight was calibrated to 14 
percent moisture basis. Water irrigation was sampled then analyzed and the values were $6.23,6.3 \mathrm{ppm} \mathrm{Pb}^{2+}$ and $0.439,0.45 \mathrm{ppm} \mathrm{Ni}{ }^{2+}$ and $0.032,0.037$ ppm $\mathrm{Cd}^{2+}$ in 2007 and 2008 seasons respectively. All plant samples were oven dried at $70 \mathrm{c}$ for 48 hours then grounded and kept in plastic pages for analysis and determined using the model of atomic absorption. The analysis of FYM showed that the $\mathrm{Pb}^{2+}$ was 45 and $46.1 \mathrm{ppm}$ with 9.2 and $9.23 \mathrm{ppm}$ $\mathrm{Ni}^{2+}$ and 3.8 and $3.82 \mathrm{ppm} \mathrm{Cd}^{2+}$ in season 2007 and 2008 respectively.

Table 1: Some mechanical, chemical characteristics of the used soil in season 2007 and 2008.

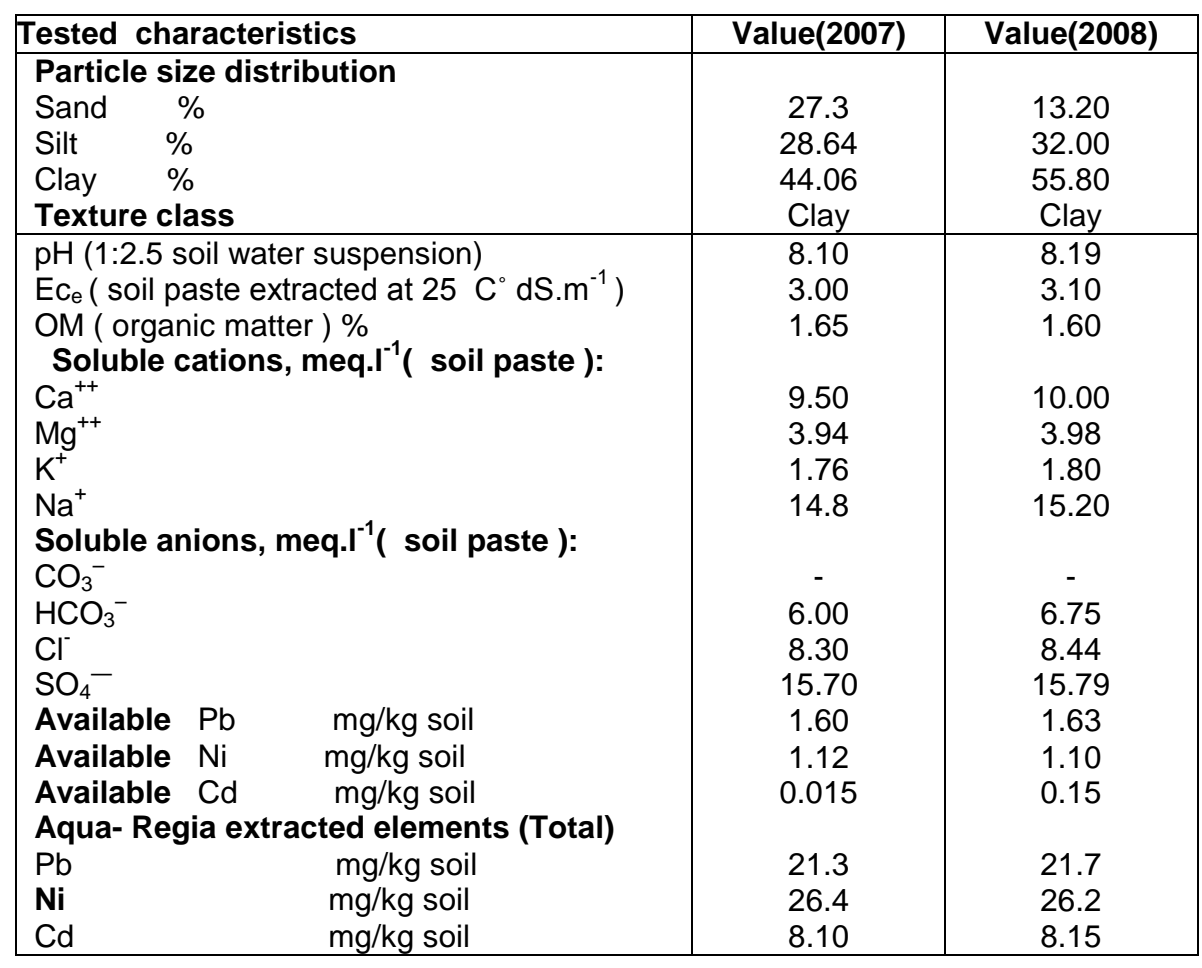

\section{RESULTS AND DISCUSSION}

Yield and yield attributes:

Grain and straw yield:

Data in Tables 2 and 3 shows the effect of farmyard manure (FYM) and urea treatments and their combinations on grain and straw yield of Giza178 rice variety during 2007 and 2008 seasons. Data showed that, there is a significant increase in yield under all treatments over the control. The highest yield of rice grain was recorded by applications of 21.42 tons FYM plus $357 \mathrm{~kg}$ urea.ha- ${ }^{-1}$ without significant differences with using 21.42 tons FYM plus $238 \mathrm{~kg}$ urea. ha ${ }^{-1}$ but the lowest yield was observed under the treatment which received no fertilizer. The increase in grain yield with the combined use of both those source is advantageous and substantial amount 
of inorganic $\mathrm{N}$ can be saved. These mainly could be attributed to that the combined use of FYM and chemical fertilizer increase nutrients availability for plant through their growth stages. Confirmed these results (Cooke 1977 and Hammad et al., 2006).

Data illustrated that grain yield increased up to 21.42 tons FYM plus $357 \mathrm{~kg}$ urea.ha ${ }^{-1}$. Data reported also, that 21.42 tons FYM alone and 21.42 tons FYM.ha ${ }^{-1}$ plus $238 \mathrm{~kg}$ urea. ha ${ }^{-1}$ gave higher grain yield as compared to $357 \mathrm{~kg}$ urea fed ${ }^{-1}$ alone but any addition from urea to FYM gave higher grain yield than that observed with FYM alone at the same treatment. The straw yield followed the similar trend as that of rice grain.

Table 2: Means of grain yield and straw yield $\left(\mathrm{kg}^{\mathrm{h}} \mathrm{ha}^{-1}\right)$ as affected by the applications of farmyard manure (FYM) and urea treatments at harvest in 2007 season.

\begin{tabular}{|l|c|c|c|c|c|c|}
\hline Treatments & $\begin{array}{c}\text { Urea } \\
\text { kg. ha }\end{array}$ & $\begin{array}{c}\text { FYM } \\
\text { t. ha }\end{array}$ & $\begin{array}{c}\text { Grain } \\
\text { kg. ha }^{-1}\end{array}$ & $\begin{array}{c}\text { \% increase } \\
\text { or decrease }\end{array}$ & $\begin{array}{c}\text { Straw } \\
\text { kg. ha }^{-1}\end{array}$ & $\begin{array}{c}\text { \% increase } \\
\text { or decrease }\end{array}$ \\
\hline $\mathrm{N}_{0} \mathrm{~F}_{0}$ & 0 & 0 & $6913.9 \mathrm{~h}$ & - & $8181.25 \mathrm{~h}$ & - \\
$\mathrm{N}_{0} \mathrm{~F}_{1}$ & 0 & 7.14 & $8901.20 \mathrm{f}$ & 28.74 & $9939.59 \mathrm{~g}$ & 21.49 \\
$\mathrm{~N}_{0} \mathrm{~F}_{2}$ & 0 & 14.28 & $9282.0 \mathrm{e}$ & 38.12 & $11314.99 \mathrm{e}$ & 38.30 \\
$\mathrm{~N}_{0} \mathrm{~F}_{3}$ & 0 & 21.42 & $11197.7 \mathrm{~b}$ & 61.96 & $11824.31 \mathrm{~d}$ & 44.52 \\
& & & & & & \\
$\mathrm{~N}_{1} \mathrm{~F}_{0}$ & 238 & 0 & $8146.74 \mathrm{~g}$ & 17.83 & $9936.5 \mathrm{~g}$ & 21.45 \\
$\mathrm{~N}_{1} \mathrm{~F}_{1}$ & 238 & 7.14 & $10072.16 \mathrm{~d}$ & 45.67 & $11638.2 \mathrm{~d}$ & 42.25 \\
$\mathrm{~N}_{1} \mathrm{~F}_{2}$ & 238 & 14.28 & $10805.2 \mathrm{c}$ & 56.28 & $12292.7 \mathrm{c}$ & 50.25 \\
$\mathrm{~N}_{1} \mathrm{~F}_{3}$ & 238 & 21.42 & $11501.35 \mathrm{ab}$ & 66.36 & $12619.95 \mathrm{~b}$ & 54.25 \\
& & & & & & \\
$\mathrm{~N}_{2} \mathrm{~F}_{0}$ & 357 & 0 & $10231.62 \mathrm{~d}$ & 34.25 & $10680.25 \mathrm{f}$ & 30.54 \\
$\mathrm{~N}_{2} \mathrm{~F}_{1}$ & 357 & 7.14 & $10692.15 \mathrm{c}$ & 54.64 & $11650.1 \mathrm{~d}$ & 42.40 \\
$\mathrm{~N}_{2} \mathrm{~F}_{2}$ & 357 & 14.28 & $11278.10 \mathrm{ab}$ & 63.12 & $12608.05 \mathrm{~b}$ & 54.10 \\
$\mathrm{~N}_{2} \mathrm{~F}_{3}$ & 357 & 21.42 & $11596.55 \mathrm{a}$ & 68.08 & $13163.185 \mathrm{a}$ & 60.89 \\
\hline
\end{tabular}

Table 3: Means of grain yield and straw yield $\left(\mathrm{kg} \mathrm{ha}^{-1}\right)$ as affected by the applications of farmyard manure (FYM) and urea treatments at harvest in 2008 season.

\begin{tabular}{|l|c|c|c|c|c|c|}
\hline Treatments & $\begin{array}{c}\text { Urea } \\
\text { kg. ha }\end{array}$ & $\begin{array}{c}\text { FYM } \\
\text { t. ha }\end{array}$ & $\begin{array}{c}\text { Grain } \\
\text { kg. ha }^{-1}\end{array}$ & $\begin{array}{c}\text { \% increase } \\
\text { or decrease }\end{array}$ & $\begin{array}{c}\text { Straw } \\
\text { kg. ha }^{-1}\end{array}$ & $\begin{array}{c}\text { \% increase } \\
\text { or decrease }\end{array}$ \\
\hline $\mathrm{N}_{0} \mathrm{~F}_{0}$ & 0 & 0 & $7057.48 \mathrm{~g}$ & - & $8330 \mathrm{~h}$ & - \\
$\mathrm{N}_{0} \mathrm{~F}_{1}$ & 0 & 7.14 & $9111.42 \mathrm{~d}$ & 29.10 & $10124.52 \mathrm{~g}$ & 21.54 \\
$\mathrm{~N}_{0} \mathrm{~F}_{2}$ & 0 & 14.28 & $9440.65 \mathrm{c}$ & 33.76 & $11608.04 \mathrm{e}$ & 39.51 \\
$\mathrm{~N}_{0} \mathrm{~F}_{3}$ & 0 & 21.42 & $11641.36 \mathrm{~b}$ & 64.95 & $11840.5 \mathrm{~d}$ & 42.30 \\
& & & & & & \\
$\mathrm{~N}_{1} \mathrm{~F}_{0}$ & 238 & 0 & $8540.22 \mathrm{f}$ & 21.00 & $9983.29 \mathrm{~g}$ & 19.98 \\
$\mathrm{~N}_{1} \mathrm{~F}_{1}$ & 238 & 7.14 & $10422.80 \mathrm{c}$ & 47.68 & $1078.14 \mathrm{de}$ & 41.51 \\
$\mathrm{~N}_{1} \mathrm{~F}_{2}$ & 238 & 14.28 & $10933.72 \mathrm{~b}$ & 54.92 & $12344.25 \mathrm{c}$ & 48.19 \\
$\mathrm{~N}_{1} \mathrm{~F}_{3}$ & 238 & 21.42 & $11696.10 \mathrm{a}$ & 65.72 & $12669.25 \mathrm{~b}$ & 52.09 \\
& & & & & & \\
$\mathrm{~N}_{2} \mathrm{~F}_{0}$ & 357 & 0 & $103337.91 \mathrm{c}$ & 46.48 & $10700.48 \mathrm{f}$ & 28.45 \\
$\mathrm{~N}_{2} \mathrm{~F}_{1}$ & 357 & 7.14 & $10845.66 \mathrm{~b}$ & 53.67 & $11686.58 \mathrm{de}$ & 40.29 \\
$\mathrm{~N}_{2} \mathrm{~F}_{2}$ & 357 & 14.28 & $11499.35 \mathrm{a}$ & 62.93 & $12669.52 \mathrm{~b}$ & 52.09 \\
$\mathrm{~N}_{2} \mathrm{~F}_{3}$ & 357 & 21.42 & $11798.44 \mathrm{a}$ & 67.17 & $13224.85 \mathrm{a}$ & 58.76 \\
\hline
\end{tabular}




\section{Lead $\left(\mathrm{Pb}^{2+}\right)$ concentration in rice plant organs:}

High $\mathrm{Pb}$ concentration has found to inhibit seed germination, stomata opening, shoot transpiration, $\mathrm{CO}_{2}$ uptake, apparent photosynthesis, and photorespiration in plant (Poskuta et al, 1987).

Data in Tables 4 and 5 Show $\mathrm{Pb}^{2+}$ concentrations in rice plant organs as affected by the application of FYM and urea treatments and their combinations.

The obtained results showed that generally, $\mathrm{Pb}^{2+}$ concentrations in organs of rice plant progressively increased with increase FYM addition levels to the soil either alone or in combinations with urea as compared with the control. These results are in harmony with those obtained by Hala (2005) who observed that the organic manures led to more significantly positive increase in the concentrations of $\mathrm{Pb}^{2+}, \mathrm{Ni}^{2+}$ and $\mathrm{Cd}^{2+}$ in roots, shoots and grain of corn plant. The highest values of $\mathrm{Pb}^{2+}$ concentrations were attained at 21.42 tons FYM plus $357 \mathrm{~kg}$ urea $\mathrm{ha}^{-1}$. Means of $\mathrm{Pb}^{2+}$ concentrations were 4 folds approximately for roots with compared to the rice straw at all treatments. While means of $\mathrm{Pb}^{2+}$ concentrations were 10 folds approximately for straw compared to grains at FYM added alone or FYM plus 238 or $357 \mathrm{~kg}$ urea.ha ${ }^{-1}$.

The critical levels of $\mathrm{Pb}^{2+}$ concentration ranged between 30 to 300 ppm (Alloway 1995). Data in Tables 5 and 6 also, indicated that $\mathrm{Pb}^{2+}$ concentration in rice straw do not exceed the safety limits (less than $30 \mathrm{ppm}$ ) of $\mathrm{Pb}^{2+}$ at all addition levels of FYM added to the soil either alone or in combinations with urea. Concerning to, the chemical analysis of rice grain, data show that the $\mathrm{Pb}^{2+}$ concentrations increased with increasing levels of FYM added to the soil whether, alone or integrations with urea in whole grain, husk and white grain, according to, $\mathrm{Pb}^{2+}$ limits in rice grains which, reported by (Kasno, 2000). It can be notice that $\mathrm{Pb}^{2+}$ concentration in white rice grains was slightly polluted at 21.42 tons FYM plus either 238 or $357 \mathrm{~kg}^{\text {urea.ha }}{ }^{-1}$ treatments, while $\mathrm{Pb}$ concentration in rice grains were unpolluted at all addition levels of FYM added to the soil alone except the treatment of 21.42 ton FYM .fed ${ }^{-1}$. These results agreed with the findings of Kashem and Singh (2001). It is clear from the data these treatments of FYM under this condition did not reach the critical levels of $\mathrm{Pb}$ concentrations in rice straw and grains. This may be due to organic matter is known to increase the capacity of the soils to adsorb $\mathrm{Pb}$ (Hala 2005). Data also, illustrated that the highest values of $\mathrm{Pb}$ concentrations were recorded with rice husk as compared to Whole and white grains at all different levels of FYM added to the soil either alone or in combinations with urea.

\section{Nickel $\left(\mathrm{Ni}^{2+}\right)$ concentration in rice plant organs:}

There is no evidence of an essential role of $\mathrm{Ni}^{2+}$ in plant metabolism, although the reported beneficial effects of $\mathrm{Ni}^{2+}$ on plant growth have stimulated speculation that this metal may have some function in plant. 
Hammad, S. A. et al.

Table 4: the Lead $(\mathrm{Pb})$ concentration $(\mathrm{ppm})$ in rice plant organs as affected by the application of farmyard manure (FYM) and urea treatments at harvest stage in 2007 season.

\begin{tabular}{|l|l|l|l|l|l|l|l|}
\hline Treatments & $\begin{array}{c}\text { Urea } \\
\text { kg.ha }^{-1}\end{array}$ & $\begin{array}{c}\text { FYM } \\
\text { t.ha }^{-1}\end{array}$ & Roots & Straw & $\begin{array}{c}\text { Whole } \\
\text { grain }\end{array}$ & Husk & $\begin{array}{c}\text { White } \\
\text { grain }\end{array}$ \\
\hline $\mathbf{N}_{\mathbf{0}} \mathbf{F}_{\mathbf{0}}$ & $\mathbf{0}$ & $\mathbf{0}$ & 30.17 & 6.42 & 0.556 & 0.783 & 0.318 \\
\hline $\mathbf{N}_{\mathbf{0}} \mathbf{F}_{\mathbf{1}}$ & $\mathbf{0}$ & $\mathbf{7 . 1 4}$ & 37.12 & 8.50 & 0.753 & 0.925 & 0.413 \\
\hline $\mathbf{N}_{\mathbf{0}} \mathbf{F}_{\mathbf{2}}$ & $\mathbf{0}$ & $\mathbf{1 4 . 2 8}$ & 50.45 & 12.40 & 1.226 & 1.873 & 0.489 \\
\hline $\mathbf{N}_{\mathbf{0}} \mathbf{F}_{\mathbf{3}}$ & $\mathbf{0}$ & $\mathbf{2 1 . 4 2}$ & 61.55 & 14.55 & 1.426 & 2.353 & 1.030 \\
\hline $\mathbf{M e a n}$ & & 44.82 & 10.46 & 0.990 & 1.480 & 0.562 \\
\hline $\mathbf{N}_{\mathbf{1}} \mathbf{F}_{\mathbf{0}}$ & $\mathbf{2 3 8}$ & $\mathbf{0}$ & 32.45 & 6.80 & 0.605 & 0.809 & 0.403 \\
\hline $\mathbf{N}_{\mathbf{1}} \mathbf{F}_{\mathbf{1}}$ & $\mathbf{2 3 8}$ & $\mathbf{7 . 1 4}$ & 42.92 & 10.02 & 0.878 & 1.253 & 0.467 \\
\hline $\mathbf{N}_{\mathbf{1}} \mathbf{F}_{\mathbf{2}}$ & $\mathbf{2 3 8}$ & $\mathbf{1 4 . 2 8}$ & 54.97 & 12.90 & 1.428 & 1.986 & 0.523 \\
\hline $\mathbf{N}_{\mathbf{1}} \mathbf{F}_{\mathbf{3}}$ & $\mathbf{2 3 8}$ & $\mathbf{2 1 . 4 2}$ & 68.37 & 15.57 & 1.536 & 2.330 & 1.250 \\
\hline $\mathbf{M e a n}$ & & & 49.67 & 11.32 & 1.110 & 1.590 & 0.656 \\
\hline $\mathbf{N}_{\mathbf{2}} \mathbf{F}_{\mathbf{0}}$ & $\mathbf{3 5 7}$ & $\mathbf{0}$ & 31.07 & 6.44 & 0.570 & 0.789 & 0.630 \\
\hline $\mathbf{N}_{\mathbf{2}} \mathbf{F}_{\mathbf{1}}$ & $\mathbf{3 5 7}$ & $\mathbf{7 . 1 4}$ & 54.07 & 12.37 & 1.160 & 1.735 & 0.506 \\
\hline $\mathbf{N}_{\mathbf{2}} \mathbf{F}_{\mathbf{2}}$ & $\mathbf{3 5 7}$ & $\mathbf{1 4 . 2 8}$ & 58.95 & 13.60 & 1.350 & 1.838 & 0.817 \\
\hline $\mathbf{N}_{\mathbf{2}} \mathbf{F}_{\mathbf{3}}$ & $\mathbf{3 5 7}$ & $\mathbf{2 1 . 4 2}$ & 68.40 & 16.50 & 1.505 & 2.417 & 1.430 \\
\hline Mean & & 53.12 & 12.22 & 1.460 & 1.690 & 0.778 \\
\hline
\end{tabular}

Table 5: Lead $(\mathrm{Pb})$ concentration $(\mathrm{ppm})$ in rice plant organs as affected by the application of farmyard manure (FYM) and urea treatments at harvest stage in 2008 season.

\begin{tabular}{|c|c|c|c|c|c|c|c|}
\hline Treatments & $\begin{array}{c}\text { Urea } \\
\text { kg.ha }^{-1}\end{array}$ & $\begin{array}{l}\text { FYM } \\
\text { t.ha }^{-1}\end{array}$ & Roots & Straw & $\begin{array}{l}\text { Whole } \\
\text { grain }\end{array}$ & Husk & $\begin{array}{l}\text { White } \\
\text { grain }\end{array}$ \\
\hline $\mathrm{N}_{0} \mathrm{~F}_{0}$ & 0 & 0 & 31.50 & 6.84 & 0.563 & 0.791 & 0.325 \\
\hline $\mathrm{N}_{0} \mathrm{~F}_{1}$ & 0 & 7.14 & 39.90 & 9.30 & 0.768 & 0.953 & 0.426 \\
\hline $\mathrm{N}_{0} \mathrm{~F}_{2}$ & 0 & 14.28 & 54.40 & 12.90 & 1.435 & 1.898 & 0.496 \\
\hline $\mathrm{N}_{0} \mathrm{~F}_{3}$ & 0 & 21.42 & 63.60 & 15.66 & 1.473 & 2.452 & 1.110 \\
\hline Mean & & & 47.35 & 11.17 & 1.05 & 1.52 & 0.589 \\
\hline $\mathbf{N}_{1} \mathrm{~F}_{0}$ & 238 & 0 & 33.40 & 7.10 & 0.618 & 0.829 & 0.423 \\
\hline $\mathrm{N}_{1} \mathrm{~F}_{1}$ & 238 & 7.14 & 45.90 & 11.12 & 0.891 & 1.355 & 0.478 \\
\hline $\mathbf{N}_{1} \mathbf{F}_{2}$ & 238 & 14.28 & 56.80 & 13.80 & 1.453 & 2.001 & 0.650 \\
\hline $\mathrm{N}_{1} \mathrm{~F}_{3}$ & 238 & 21.42 & 71.80 & 17.0 & 1.582 & 2.410 & 1.310 \\
\hline Mean & & & 51.79 & 12.25 & 1.15 & 1.66 & 0.715 \\
\hline $\mathrm{N}_{2} \mathrm{~F}_{0}$ & 357 & 0 & 34.50 & 7.30 & 0.625 & 0.835 & 0.652 \\
\hline $\mathrm{N}_{2} \mathrm{~F}_{1}$ & 357 & 7.14 & 57.30 & 14.0 & 1.225 & 1.863 & 0.662 \\
\hline $\mathrm{N}_{2} \mathrm{~F}_{2}$ & 357 & 14.28 & 62.81 & 15.60 & 1.481 & 1.921 & 0.845 \\
\hline $\mathrm{N}_{2} \mathrm{~F}_{3}$ & 357 & 21.42 & 73.80 & 17.80 & 1.601 & 2.513 & 1.501 \\
\hline Mean & & & 57.10 & 13.67 & 1.233 & 1.783 & 0.915 \\
\hline
\end{tabular}

$\mathrm{Ni}^{2+}$ is an essential component of the enzyme urease and stimulation effects of $\mathrm{Ni}^{2+}$ on the nitrification and mineralization of $\mathrm{N}$ compounds (Kabata - pendias and pendias 2000). Data in Tables 6 and 7 represent $\mathrm{Ni}^{2+}$ concentration in rice plant organs through different stages as affected by the application of FYM and urea treatments and their integrations. Results stated that, $\mathrm{Ni}^{2+}$ concentration in organs of plant progressively increased with increasing levels of FYM added either alone or in integrations with urea compared with the control. This could be attributed to: 
1) Soil organic matter complexes $\mathrm{Ni}^{2+}$ and soluble organic compounds can increase the solubility and consequent increase the available $\mathrm{Ni}^{2+}$ and its absorption by plant

2) Nickel is readily translocated through xylem as negatively charged organic matter complex (Sarivastava and Gupata 1996).

The highest values of $\mathrm{Ni}^{2+}$ concentrations were recorded at 21.14 tons $\mathrm{FYM}$ plus $357 \mathrm{~kg}$ urea ha $^{-1}$. Concerning to Ni concentration in rice plant organs, data also, state that roots accumulated more $\mathrm{Ni}^{2+}$ than straw and grains. These results agreed with the findings of Srivastava and Gupata (1996) who found that most of observed $\mathrm{Ni}$ accumulates in the roots. The concentration of $\mathrm{Ni}^{2+}$ is much lower in leaves, stems and seeds than roots. This finding might be attributed to the fact that plant roots are the first organs in contact with the toxic metal solute (Marchiol et al., 1996). Means of $\mathrm{Ni}^{2+}$ concentrations were 3.6 folds approximately for roots as compared to straw at all treatments. The respective values of mean $\mathrm{Ni}^{2+}$ concentrations were about 6 folds for straw as compared to with grains at all treatments. Relating to, the chemical analysis of rice grain indicated that the $\mathrm{Ni}^{2+}$ concentration increased with increasing levels of FYM added to the soil either alone or in combinations with urea in whole grain, husk and white grain. These results are in harmony with those obtained by Hala (2005). The rice husk analyzed was higher in concentration of $\mathrm{Ni}^{2+}$ compared with whole and weight grains at all addition levels of FYM. This means that, heavy metals concentrated in husk than grains. These results agreed with the findings of Sarkunan et al (1991) and Howida (2004). $\mathrm{Ni}^{2+}$ concentrations in rice plant did not exceed the critical limits at all treatments. Also, the results are in harmony with those obtain by Chino (1981) who found that the toxic of $\mathrm{Ni}^{2+}$ concentrations in the foliage was found to be 20 to $50 \mathrm{ppm}$ in rice.

Table 6: The nickel ( $\mathrm{Ni})$ concentration (ppm) in rice plant organs as affected by the application of farm yard manure (FYM) and urea treatments at harvest stage in 2007 season.

\begin{tabular}{|c|c|c|c|c|c|c|c|}
\hline Treatments & $\begin{array}{l}\text { Urea } \\
\text { kg.ha }{ }^{-1}\end{array}$ & $\begin{array}{l}\text { FYM } \\
\text { t.ha }^{-1}\end{array}$ & Roots & Straw & $\begin{array}{l}\text { Whole } \\
\text { grain }\end{array}$ & Husk & $\begin{array}{l}\text { White } \\
\text { grain }\end{array}$ \\
\hline $\mathrm{N}_{0} \mathrm{~F}_{0}$ & 0 & 0 & 34.87 & 8.67 & 1.31 & 1.60 & 0.356 \\
\hline $\mathrm{N}_{0} \mathrm{~F}_{1}$ & 0 & 7.14 & 42.07 & 11.14 & 1.85 & 1.93 & 0.489 \\
\hline $\mathrm{N}_{0} \mathrm{~F}_{2}$ & 0 & 14.28 & 52.07 & 13.22 & 2.25 & 2.68 & 0.612 \\
\hline $\mathrm{N}_{0} \mathrm{~F}_{3}$ & 0 & 21.42 & 61.32 & 16.57 & 2.80 & 2.90 & 0.859 \\
\hline Mean & & & 47.58 & 12.40 & 2.07 & 2.27 & 0.579 \\
\hline $\mathbf{N}_{1} \mathbf{F}_{0}$ & 238 & 0 & 42.82 & 10.95 & 1.83 & 1.92 & 0.396 \\
\hline $\mathbf{N}_{1} \mathbf{F}_{1}$ & 238 & 7.14 & 48.32 & 12.65 & 2.28 & 2.60 & 0.501 \\
\hline $\mathbf{N}_{1} \mathbf{F}_{2}$ & 238 & 14.28 & 56.80 & 15.45 & 2.72 & 3.00 & 0.790 \\
\hline $\mathbf{N}_{1} \mathbf{F}_{3}$ & 238 & 21.42 & 6352 & 17.50 & 2.98 & 3.23 & 0.983 \\
\hline Mean & & & 52.86 & 14.40 & 2.45 & 2.68 & 0.667 \\
\hline $\mathrm{N}_{2} \mathrm{~F}_{0}$ & 357 & 0 & 45.12 & 11.44 & 1.87 & 2.11 & 0.480 \\
\hline $\mathbf{N}_{2} \mathrm{~F}_{1}$ & 357 & 7.14 & 51.15 & 14.12 & 2.41 & 2.80 & 0587 \\
\hline $\mathrm{N}_{2} \mathrm{~F}_{2}$ & 357 & 14.28 & 63.05 & 18.05 & 2.97 & 3.25 & 0580 \\
\hline $\mathrm{N}_{2} \mathrm{~F}_{3}$ & 357 & 21.42 & 69.67 & 20.07 & 3.27 & 3.63 & 1.150 \\
\hline Mean & & & 57.24 & 15.92 & 2.63 & 2.94 & 0.770 \\
\hline
\end{tabular}


Hammad, S. A. et al.

Table 7: The nickel (Ni) concentration (ppm) in rice plant organs as affected by the application of farm yard manure (FYM) and urea treatments at harvest stage in 2008 season.

\begin{tabular}{|c|c|c|c|c|c|c|c|}
\hline Treatments & $\begin{array}{l}\text { Urea } \\
\text { kg.ha }{ }^{-1}\end{array}$ & $\begin{array}{l}\text { FYM } \\
\text { t.ha }^{-1}\end{array}$ & Roots & Straw & $\begin{array}{l}\text { Whole } \\
\text { grain }\end{array}$ & Husk & $\begin{array}{l}\text { White } \\
\text { grain }\end{array}$ \\
\hline $\mathrm{N}_{0} \mathrm{~F}_{0}$ & 0 & 0 & 35.80 & 8.92 & 1.34 & 1.67 & 0.362 \\
\hline $\mathrm{N}_{0} \mathrm{~F}_{1}$ & 0 & 7.14 & 45.07 & 12.80 & 1.90 & 2.07 & 0.490 \\
\hline $\mathrm{N}_{0} \mathrm{~F}_{2}$ & 0 & 14.28 & 55.80 & 14.80 & 2.31 & 2.78 & 0.663 \\
\hline $\mathrm{N}_{0} \mathrm{~F}_{3}$ & 0 & 21.42 & 65.70 & 18.00 & 2.91 & 3.08 & 0.890 \\
\hline Mean & & & 50.59 & 13.63 & 2.31 & 2.27 & 0.601 \\
\hline $\mathbf{N}_{1} \mathbf{F}_{0}$ & 238 & 0 & 43.80 & 11.80 & 1.80 & 1.88 & 0.382 \\
\hline $\mathbf{N}_{1} \mathrm{~F}_{1}$ & 238 & 7.14 & 50.80 & 13.75 & 2.35 & 2.81 & 0.563 \\
\hline $\mathrm{N}_{1} \mathrm{~F}_{2}$ & 238 & 14.28 & 58.99 & 16.17 & 2.89 & 3.19 & 0.8 .01 \\
\hline$N_{1} F_{3}$ & 238 & 21.42 & 66.80 & 18.90 & 2.97 & 3.25 & 0.993 \\
\hline Mean & & & 55.09 & 15.15 & 2.502 & 2.78 & 0.684 \\
\hline $\mathrm{N}_{2} \mathrm{~F}_{0}$ & 357 & 0 & 46.12 & 11.80 & 1.80 & 2.15 & 0.450 \\
\hline $\mathrm{N}_{2} \mathrm{~F}_{1}$ & 357 & 7.14 & 53.52 & 15.10 & 2.52 & 2.91 & 0.601 \\
\hline $\mathrm{N}_{2} \mathrm{~F}_{2}$ & 357 & 14.28 & 63.80 & 17.83 & 3.12 & 3.53 & 0.631 \\
\hline $\mathrm{N}_{2} \mathrm{~F}_{3}$ & 357 & 21.42 & 71.80 & 21.90 & 3.27 & 3.63 & 1.150 \\
\hline Mean & & & 58.81 & 16.65 & 2.67 & 3.055 & 0.708 \\
\hline
\end{tabular}

\section{Cadmium $\left(\mathrm{Cd}^{2+}\right)$ concentration in rice plant organs:}

Regular consumption of plants containing $3 \mathrm{ppm} \mathrm{Cd}^{2+}$ can poison man and animal, it interferes with and other proteins. In livestock, it accumulates in kidneys, spleen and liver (Tuker et al., 2003). Data in Tables 8 and 9 represent $\mathrm{Cd}^{2+}$ concentration in rice plant organs through different stages as affected by the application of FYM and urea treatment and their combinations. Results indicated that $\mathrm{Cd}^{2+}$ concentration in plant organs progressively increased with increment FYM levels added to the soil whether separated or combined with urea at all stages as compared to the control. This is may be due to:

1- The content of FYM from $\mathrm{Cd}^{2+}$

2-The mobility in alkaline soil due to the formation of complexes or metal chelats, 3-The plant uptake of $\mathrm{Cd}^{2+}$ may be indepented of the $\mathrm{pH}$ (Kitagishi and Yamane 1981). Also, Srivastava and Gupta (1996) who found that the fixation of $\mathrm{Cd}$ by organic matter is operative under the acidic condition (soil $\mathrm{pH} 4-6$ ) but the solubilization of $\mathrm{Cd}^{2+}$ by organic matter occurs in the range of the soil $\mathrm{pH} 7-8$. The highest values of $\mathrm{Cd}^{2+}$ concentration were achieved at 9 tons FYM plus $357 \mathrm{~kg}$ urea.ha ${ }^{-1}$. As compare the $\mathrm{Cd}^{2+}$ concentrations in different plant organs, data in Tables 9 and 10 revealed that roots accumulated higher $\mathrm{Cd}^{2+}$ level than shoots, straw and grain at all stages. These results agreed with findings of Kabata- Pendias and Pendias (2000) and Kabata-pendias and Mukherjee (2007) who found that usually $\mathrm{Cd}^{2+}$ concentration is the highest in roots and decreases towards the top plants. The obtained results also, showed that mean $\mathrm{Cd}^{2+}$ concentration was approximately 3 and 10 folds for roots as compared to straw and grains respectively at all treatments at harvest stage. The normal range of $\mathrm{Cd}^{2+}$ concentration in plants was 0.10 to $2.40 \mathrm{ppm}$, while the critical level ranged between 5 to $30 \mathrm{ppm}$ (Alloway 1995). The obtained data also, illustrated that $\mathrm{Cd}^{2+}$ concentration in rice straw don't exceed the critical levels of $\mathrm{Cd}^{2+}$ 
at all addition levels of FYM added to the soil whether, separated or in integrated with urea accordance with limits as mentioned before. The chemical analysis of rice grain showed that the concentration of $\mathrm{Cd}^{2+}$ increased with increasing levels of FYM added separated or combined with urea in whole grains, husk and white grains.

In Japan, the maximum level of $\mathrm{Cd}^{2+}$ in unpolished rice grain is $1.00 \mathrm{mg}$ Cd. $\mathrm{kg}^{-1}$. In Taiwan, it is $0.50 \mathrm{mg} \mathrm{Cd}$. kg-1 while in mainland China the maximum permitted level is $0.40 \mathrm{mg} \mathrm{Cd} \mathrm{kg}^{-1}$ in polished rice grain (Chen ,2000).

According to, Cd limits in rice grain as mentioned before and limits reported by (Kasno 2000). It can be observed that $\mathrm{Cd}$ concentration in rice grain was polluted at 21.14 tons FYM plus $238 \mathrm{~kg}^{\text {urea.ha }}{ }^{-1}(0.530 \mathrm{ppm})$, 14.28 tons FYM plus $357 \mathrm{~kg}$ urea. $\mathrm{ha}^{-1}(0.701 \mathrm{ppm})$ and 21.14 tons plus 357 $\mathrm{kg}$ urea.ha ${ }^{-1}(1.10 \mathrm{ppm})$.

Results also, showed that the rice husk analyzed was higher in concentration of $\mathrm{Cd}^{2+}$ compared with whole and white grain at all addition levels of FYM. This means that, $\mathrm{Cd}^{2+}$ concentrated in husk than grains. These results agreed with findings of Sarkunan et al (1991) and Howida (2004). In fact, it is clear that the integration of 14.28 tons FYM plus $238 \mathrm{~kg}$ urea.ha ${ }^{-1}$ was safe for all heavy metals under this study.

Table 8: The cadmium $\left(\mathrm{Cd}^{2+)}\right.$ concentration (ppm) in rice plant organs as affected by the application of farmyard manure (FYM) and urea treatments at harvest stage in 2007 season.

\begin{tabular}{|c|c|c|c|c|c|c|c|}
\hline Treatments & $\begin{array}{l}\text { Urea } \\
\text { kg.ha }^{-1}\end{array}$ & $\begin{array}{l}\text { FYM } \\
\text { t.ha }^{-1}\end{array}$ & Roots & Straw & $\begin{array}{l}\text { Whole } \\
\text { grain }\end{array}$ & Husk & $\begin{array}{l}\text { White } \\
\text { grain }\end{array}$ \\
\hline $\mathrm{N}_{0} \mathrm{~F}_{0}$ & 0 & 0 & 4.93 & 1.60 & 0.450 & 0.730 & 0.275 \\
\hline $\mathrm{N}_{0} \mathrm{~F}_{1}$ & 0 & 7.14 & 5.52 & 1.93 & 0.560 & 0.810 & 0.367 \\
\hline $\mathrm{N}_{0} \mathrm{~F}_{2}$ & 0 & 14.28 & 6.19 & 2.15 & 0.640 & 0.920 & 0.400 \\
\hline $\mathrm{N}_{0} \mathrm{~F}_{3}$ & 0 & 21.42 & 7.30 & 2.50 & 0.750 & 1.100 & 0.480 \\
\hline Mean & & & 5.98 & 2.04 & 0.600 & 0.890 & 0.380 \\
\hline $\mathbf{N}_{1} \mathrm{~F}_{0}$ & 238 & 0 & 5.10 & 1.67 & 0.480 & 0.750 & 0.289 \\
\hline $\mathrm{N}_{1} \mathrm{~F}_{1}$ & 238 & 7.14 & 6.60 & 2.10 & 0.590 & 0.890 & 0.392 \\
\hline $\mathrm{N}_{1} \mathrm{~F}_{2}$ & 238 & 14.28 & 7.73 & 2.60 & 0.740 & 0.993 & 0480 \\
\hline $\mathbf{N}_{1} \mathrm{~F}_{3}$ & 238 & 21.42 & 9.00 & 3.30 & 0.921 & 1.230 & 0.530 \\
\hline Mean & & & 7.10 & 2.41 & 0.682 & 0.960 & 0.554 \\
\hline $\mathrm{N}_{2} \mathrm{~F}_{0}$ & 357 & 0 & 5.80 & 1.83 & 0.545 & 0.810 & 0.320 \\
\hline $\mathrm{N}_{2} \mathrm{~F}_{1}$ & 357 & 7.14 & 7.50 & 2.50 & 0.760 & 0.920 & 0.520 \\
\hline $\mathrm{N}_{2} \mathrm{~F}_{2}$ & 357 & 14.28 & 8.60 & 2.90 & 0.900 & 1.200 & 0.701 \\
\hline $\mathrm{N}_{2} \mathrm{~F}_{3}$ & 357 & 21.42 & 10.00 & 3.50 & 1.200 & 1.560 & 1.100 \\
\hline Mean & & & 7.97 & 2.65 & 0.826 & 1.120 & 0.652 \\
\hline
\end{tabular}


Hammad, S. A. et al.

Table 9: The cadmium $\left(\mathrm{Cd}^{2+)}\right.$ concentration (ppm) in rice plant organs as affected by the application of farmyard manure (FYM) and urea treatments at harvest stage in 2008.

\begin{tabular}{|c|c|c|c|c|c|c|c|}
\hline Treatments & $\begin{array}{l}\text { Urea } \\
\text { kg.ha }{ }^{-1}\end{array}$ & $\begin{array}{l}\text { FYM } \\
\text { t.ha }^{-1}\end{array}$ & Roots & Straw & $\begin{array}{l}\text { Whole } \\
\text { grain }\end{array}$ & Husk & $\begin{array}{l}\text { White } \\
\text { grain }\end{array}$ \\
\hline $\mathrm{N}_{0} \mathrm{~F}_{0}$ & 0 & 0 & 5.07 & 1.65 & 0.460 & 0.750 & 0.280 \\
\hline $\mathrm{N}_{0} \mathrm{~F}_{1}$ & 0 & 7.14 & 5.83 & 2.07 & 0.575 & 0.895 & 0.403 \\
\hline $\mathrm{N}_{0} \mathrm{~F}_{2}$ & 0 & 14.28 & 6.45 & 2.29 & 0.715 & 0.992 & 0.445 \\
\hline $\mathrm{N}_{0} \mathrm{~F}_{3}$ & 0 & 21.42 & 7.62 & 2.57 & 0.900 & 1.250 & 0.523 \\
\hline Mean & & & 6.242 & 2.145 & 0.662 & 0.971 & 0.412 \\
\hline $\mathbf{N}_{1} \mathbf{F}_{0}$ & 238 & 0 & 5.22 & 1.69 & 0.507 & 0.781 & 0.297 \\
\hline $\mathrm{N}_{1} \mathrm{~F}_{1}$ & 238 & 7.14 & 6.85 & 2.23 & 0.620 & 0.931 & 0.408 \\
\hline $\mathrm{N}_{1} \mathrm{~F}_{2}$ & 238 & 14.28 & 7.91 & 2.73 & 0.781 & 1.071 & 0.510 \\
\hline $\mathbf{N}_{1} F_{3}$ & 238 & 21.42 & 9.45 & 3.41 & 0.981 & 1.29 & 0.553 \\
\hline Mean & & & 7.75 & 2.51 & 0.722 & 1.018 & 0.442 \\
\hline $\mathrm{N}_{2} \mathrm{~F}_{0}$ & 357 & 0 & 5.84 & 1.90 & 0.563 & 0.890 & 0.367 \\
\hline $\mathrm{N}_{2} \mathrm{~F}_{1}$ & 357 & 7.14 & 7.71 & 2.63 & 0.791 & 0.995 & 0.534 \\
\hline $\mathrm{N}_{2} \mathrm{~F}_{2}$ & 357 & 14.28 & 9.00 & 2.98 & 0.987 & 1.301 & 0.762 \\
\hline $\mathrm{N}_{2} \mathrm{~F}_{3}$ & 357 & 21.42 & 11.50 & 3.65 & 1.295 & 1.617 & 1.15 \\
\hline Mean & & & 8.51 & 2.79 & 0.909 & 1.190 & 0.703 \\
\hline
\end{tabular}

\section{Conclusion}

Generally $\mathrm{Pb}^{2+}, \mathrm{Ni}^{2+}$ and $\mathrm{Cd}^{2+}$ concentrations in rice plant organs progressively increased with increasing the levels of FYM either alone or integrated with urea as compared with the control. Rice grain was polluted with lead and cadmium at higher levels of fertilizer, so it is important to use the recommendation level of FYM and urea to avoid the contamination such as 14.28 tons FYM plus $238 \mathrm{~kg}$ urea. $\mathrm{ha}^{-1}$.

\section{REFERENCES}

Alloway, B. J. 1995. Heavy metals in soils, $2^{\text {nd }}$ ed. Blackie Academic and profeional, New York.

Allinson. D. W. and C. Dzialo.1981.The influence of lead, cadmium, and nickel on the growth of ryegrass and oats. Plant and soil. (62) 81-89.

Chen .Z. S. 2000 .Relationship between heavy metal concentration in soils of Taiwan and uptake by crops. Department of Agricultural chemistry. National Taiwan University. Taipei 106. Taiwan, ROC.

Chino, M. 1981. Adorption, desorption, potential and selective distribution of heavy metals in selected soils of Japan. In Heavy metals pollution in soils of Japan. K. Kitagishi and Yamane, eds. Japan Scientific Press, Tokyo.

Cooke, G.W. 1977. The role of organic matter in managing soils for higher crop yields. Areview of the experimental evidence. Pages 53-64 in the proceedings of the international seminar on soil environment and fertility management in intensive agriculture. The Soci. Of the Sci. soil and manure. Japan (Nippon Adj Yohirye Gakkail, Tokoy).

Cottenie, A.; R.Camerbynck; M. Verloo and A. Dhaere. 1979. Fractionation and determination of trace elements in plants. Soils and Sediments. Pure Appl. Chem. 52: 145-153. 
Hala Kandil, A.H.2005. Impact of agricultural wastes compost on some heavy metals content in soil and plant. Ph.D. Thesis Fac of Agric., Cairo. Univ., Egypt

Hammad, S.A; K.H.EL-Hamdi; S.A.Ghanem and E.S.Naeem 2006. Grain yield of lowland (Oriza Sativa) as influenced by integrated use of urea and rice straw fertilizer. J.Agric. Sci. Mansoura Univ., 31(6) : 39933999.

Howida El-Habet. B. I. 2004. Effect of aerobic and anaerobic condition in polluted soil on heavy metals content of some crops. M. Sc. Thesis, Fac. of Agric. Minufiya. Univ., Egypt.

Kabata- Pendias, A. and H. Pendisa 1992. Trace elements in soils and plants. Crs press, inc. Boca Raton, Florida.

Kabata- Pendias, A. and H. Pendias 2000. Trace elements in soils and plants. Crs press, inc. Boca Raton London New York Washington, D.c.

Kabata- Pendias.A and A.B. Mukherjee. 2007. Trace Elements from soil to Human. CRC press, Inc. Library of Congress control Number 2007920909.

Kashem, M.A. and B.R. Singh. 2001. Metal availability in contaminated soils : 1. Effects of flooding and organic matter on changes in Eh, $\mathrm{pH}$ and solubility of $\mathrm{Cd}, \mathrm{Ni}$ and $\mathrm{Zn}$. Nutrients cycling in Agroecosystems 61: 247-255.

Kasno,A.Sri. Adiningsih, Sulaeman dan subowo.2000. Total area of intensive ppady rice contaminated by lead and cadmium Kawarang and Bekasi district, west java, Indonesia. Jurnal iimu Tanah dan lingkungan 3.2: 25-32 (in Bahasia Indonesia).

Kitagish,K and I. Yamane., Eds.1981. Heavy metals pollution in soils of Japan, Japan science society Press, Tokyo. 302

Marchiol, L.L. Leita, M. Martine A. Peressotti and G.Zerbi.1996. Physiological responses of two soybean cltivars to cadmium.J.Environ. Qual, 25: 562-566.

Mengel, K. and E. A. Kirkby 1987. Principles of plant nutrition. Han Booded. By Dr. Konard Mengel.

Page, A. L., R.H. Miller and D.R. Keeney.1982. Methods of soil Analysis part 2. Amer. Sco. Agric. Inc. Madison.

Poskuta, J.W; E parys and E. Romarovskav. 1987. The effect of lead on the gaseous exchange and photosynthetic carbon metabolism of pea seedlings. Acta Soc.Pol. 56: 127-137.

Sarkunan, v. A. Kmisra and p.k. Nayar. 1991. Effect of cadmium, nickel and copper on yield and metal content in rice (Oriza sativa). 28, 459-462.

Srivastava, P.C; and U.C. Gupta. 1996. Trace elements in crop production. Science Pulishers, Inc. 10 water street \# 310 Lebanon, NH 03766, USA.

Tuker, M.R., D.H. Hardy andC.E. Catherine. 2003. Heavy metals in North Carolina soils: occurrence and significance. Raleigh (NC) North Carolina Department of Agricultural and consumer services, Agronomic Division. ZP. 
Hammad, S. A. et al.

تركيزات عناصر النيكل و الرصاص والكادميوم في نبات الارزتاثرا بالسماد البلاى.

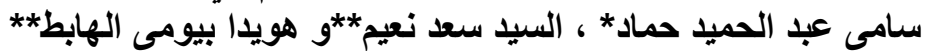

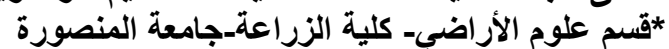

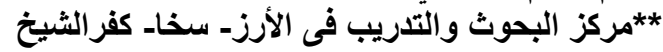

أجريت تجربتين حقليتين في موسمي 2007و 2008 في مزرعة مركز البحوث

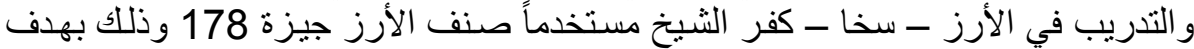

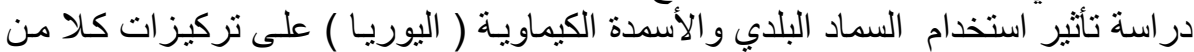

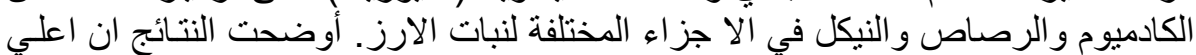

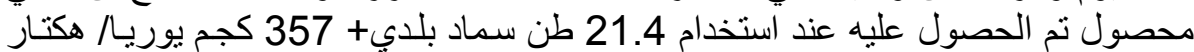

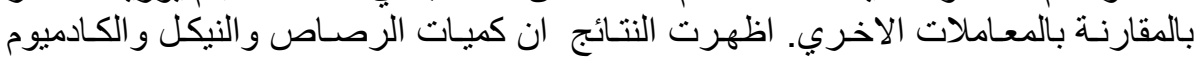

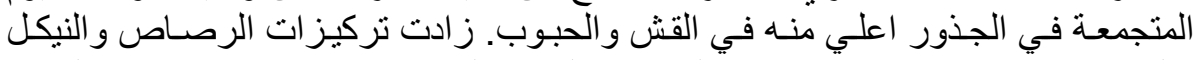

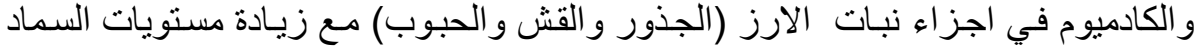

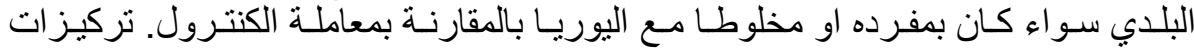

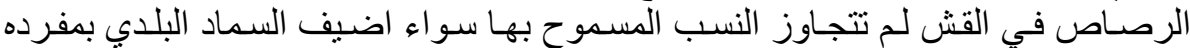

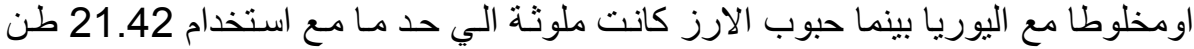

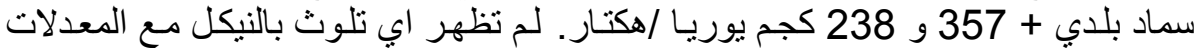

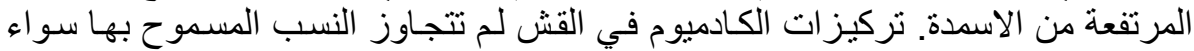

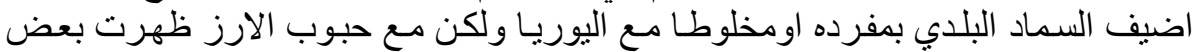

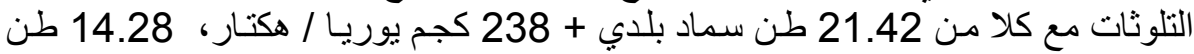

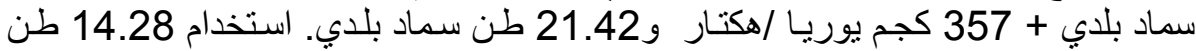

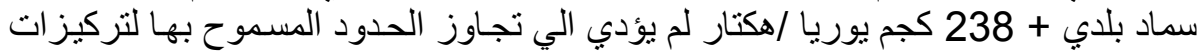
كلا من الرصاص و النيكل و الكادميوم في اجزاء نبات الإدي الارز المختلفة.

كلية الزراعة - جامعة المنصورة مركز البحوث الزراعية
قام بتحكيم البحث

أ. أد / محمد يحيى سيد العيد العرقان أ.د / عبد العظيم الطنطاوى بلدوى العمان 